urnal Ilmiah Teunuleh

The International Journal of Social Sciences

Vol. 2, Issue. 1, Mar 2021

E-ISSN: 2746-4393

\title{
THE INFLUENCE OF LEARNING STRATEGIES AND SELF-RELIANCE ON PPKN LEARNING OUTCOMES IN FIFTH GRADE AT SDN 060931 MEDAN
}

\author{
Putri Indaayu ${ }^{1}$ \\ Reh Bungana Br. Perangin-Angin² \\ Daulat Saragi ${ }^{3}$ \\ ${ }^{1,2,3}$ State University of Medan, Indonesia
}

\begin{abstract}
This study aims to: knowing the difference the result of learning PPKn students taught with the learning strategy problem based learning and concept map of learning strategies, knowing the difference result of learning PPKn students who have learning independence high with students who have learning independence is low, determine the interaction between learning strategies and self-regulated learning in affecting the learning outcomes PPKn. This research is experimental research. Population in this research is all students of class VSD Negeri No. 060931 Medan academic year 2020/2021 which consists of two classes. The sample selected by total sampling technique. The instrument used is the questionnaire of independence in student learning and test the learning outcomes of students. Data obtained from the research instrument were then analyzed using two-way ANAVA on SPSS 23.0 for Windows. The results showed that: There is a significant difference between the result of learning PPKn students taught with the learning strategy of problem based learning compared with the learning strategies concept map ( $F_{\text {count }}=23.476$ and the value of sig. $\left.0,000<0.05\right)$, the result of learning PPKn students who have learning independence higher compared with students who have learning independence low ( $F_{\text {count }}=7.673$ and the value of sig. Are $\left.0.008<0.05\right)$, and there are interaction between learning strategy and self-regulated learning in influencing the result of learning PPKn students ( $F_{\text {count }}=13.003$ and the value of sig. $0.001<0.05$ ).
\end{abstract}

Keywords: Problem Based Learning Strategy, Concept Maps, Self-Regulated Learning, Learning Outcomes 


\section{A. Introduction}

Pancasila and Citizenship Education (PPKn) is a content material in the primary school curriculum that must be taken by students in following the learning process. In the Appendix Permendiknas No. 22 Year 2006 dated May 23, 2006 about Standar isi affirmed that "The group of citizenship subjects is intended to increase awareness and insight of learners on their status, rights, and obligations in the life of society, nation, and state, as well as improving the quality of himself as a human being".

The purpose of PPKn adalah to foster the insight and awareness of the state, attitudes and behaviors that love the homeland and the unity of the nation's culture, the insight of the archipelago, as well as national resilience in the future successors of the nation who are and study and will master science and technology and art. Given the importance of PPKn that must be mastered by students, students are required to be able to follow and master PPKn in their school; the learning results from PPKn obtained by students should be able to achieve the Minimum Completion Criteria (KKM) applicable in the school and students are expected to master ppkn material.

Learning outcomes are a concern for educators, parents and students in the learning process. Many factors can support or hinder students' learning success. Fthe actor is an internal and external factor. Internal factors are factors that can influence learning outcomes from within the student himself. One of the internal factors is the independence of learning owned by students. (Rusman, 2014, p. 123)

Learning independence is a student learning process that can determine the purpose, materials and learning experience, as well as the evaluation of the learning. This learning independence can affect students' learning outcomes, because with the independence in learning, students have responsibility for the learning process and try their best to succeed in learning in order to obtain satisfactory grades. (Rusman, 2014, p. 365)

Children who have strong independence will not give up easily. Self-reliance can be demonstrated by the ability to solve problems faced with behavior. The personality of a child who has the characteristics of self-reliance positively affects his learning achievements. (Fatihah, 2016, p. 206)

Then the external factor that can affect learning outcomes is the learning strategy. Some learning strategies that can be used in the learning process are concept map learning strategies and PBL (Problem Based Learning) learning strategies. Concept map learning strategy is one of the learning strategies that can help students in organizing the 
The Influence of Learning Strategies and Self-Reliance on PPKn Learning Outcomes...

information received by students, so that students will be more active in building the knowledge they have and in processing. (Jailani, 2016, p. 117)

Other learning strategies that can be used in the learning process are PBL learning strategies. PBL is a learning strategy that exposes students to a real problem that occurs around students to be able to solve and find solutions to the problem.

Related to Problem Based Learning, Arbas Hasibuan, R. Bungana and Siman (Hasibuan, 2018) conducted research that showed the results that there is an influence of Problem Based Learning and Direct Intruction learning model on the learning outcomes of SD IT Nurul 'Ilmi Medan students. Research conducted by Riswari, Yanto, and Sunarso (2018) showed that pbl models using demonstration methods affect problem solving capabilities.

Based on the observations found that the learning outcomes of grade $V$ students at SD Negeri 060931 Medan school tend to be low or have not reached the Minimum Completion Criteria (KKM). Thus, the acquisition of student learning outcomes that are not maximized in ppkn material becomes a problem that must be solved.

\section{B. Method}

This research was conducted at SD Negeri 060931 Medan in Jalan Turi Timbang Deli Kec. Medan Amplas with the population and samples in this study are all students of grade V SD Negeri No. 060931 Medan, which consists of two classes consisting of 50 students, VA class 25 students and VB 25 students.

This research was conducted using experimental research methods. To find out the influence of learning strategies and learning independence on the learning outcomes of PPKn students researchers spread pre-tests to measure the initial ability of VA and VB grade students. In addition, researchers also disseminated a study independence questionnaire with the aim of knowing the level of student learning independence in each class. The experimental research design used is factorial $2 \times 2$. This study involved two sample groups, namely experiment group I and experiment group II. Experiment group I will be taught and treated using problem based learningstrategies, while experiment group II will be taught using concept map learning strategy. 
Putri Indaayu, Reh Bungana Br. Perangin-Angin, Daulat Saragi

\begin{tabular}{|c|c|c|}
\hline $\begin{array}{r}\text { Strategy } \\
\text { Learning }(A) \\
\text { Independence }\end{array}$ & $\begin{array}{c}\text { Problem Based } \\
\text { Learning Learning Strategy } \\
\left(\mathrm{A}_{1}\right)\end{array}$ & $\begin{array}{c}\text { Concept Map Learning } \\
\text { Strategy }\left(\mathrm{A}_{2}\right)\end{array}$ \\
\hline Height $\left(\mathrm{B}_{1}\right)$ & $\mathrm{A}_{1} \mathrm{~B}_{1}$ & $\mathrm{~A}_{2} \mathrm{~B}_{1}$ \\
\hline $\operatorname{Low}\left(\mathrm{B}_{2}\right)$ & $\mathrm{A}_{1} \mathrm{~B}_{2}$ & $\mathrm{~A}_{2} \mathrm{~B}_{2}$ \\
\hline
\end{tabular}

\section{Finding and Discussion}

\section{Finding}

\section{Learning Outcomes of PPKn Students Taught with Problem Based Learning Strategies}

Based on the data obtained and the results of statistical calculations it is known that the results of learning PPKn students who are taught with problem based learning strategies get the lowest score of 73 , and the highest score is 100 , with an average of 86.17; variants of 57.47 and standard deviation of 7.58. The distribution of the frequency of scores of students who are taught with $\mathrm{pb} /$ learning strategies is presented in the following Tabel below:

Table 1. Distribution of Frequency of Learning Outcomes of Students Taught with Problem Based Learning Strategy

\begin{tabular}{|c|c|c|}
\hline \multicolumn{3}{|c|}{ Group A } \\
\hline Interval & Frequency & Percentage (\%) \\
\hline $73-77$ & 3 & $11 \%$ \\
\hline $78-82$ & 5 & $19 \%$ \\
\hline $83-87$ & 8 & $30 \%$ \\
\hline $88-92$ & 0 & $0 \%$ \\
\hline $93-97$ & 8 & $30 \%$ \\
\hline $98-102$ & 1 & $4 \%$ \\
\hline Amount & 25 & $100 \%$ \\
\hline
\end{tabular}

From the table, the distribution of the frequency of learning outcomes of students who are taught with problem based learning strategies can be known that 2 people out of 25 students or $8 \%$ who have learning outcomes under KKM (75), while 23 students or $92 \%$ of other students have grades above KKM.

The result of learning PPKn students who are taught with problem based learning strategies the highest number of frequencies are in the interval classes 83-87 and 93-97, while theleast number of frequencies are in the interval classes 88-92. 
The Influence of Learning Strategies and Self-Reliance on PPKn Learning Outcomes...

\section{Learning Outcomes of PpKn Students Taught with Concept Map Learning Strategy}

From data obtained and statistical calculation results are known that the learning outcomes of students who are taught with concept map learning strategies get the lowest score of 63, and the highest score of 93, with an average of 78.40; a variant of 60.30 and a standard deviation of 7.77. The distribution of the frequency of scores of students who are taught with concept map learning strategies is presented in the following tabel.

Table 2. Distribution of Frequency of Learning Outcomes of Students Taught with Concept Map Learning Strategy

\begin{tabular}{|c|c|c|}
\hline \multicolumn{3}{|c|}{ Group B } \\
\hline Interval & Frequency & Percentage (\%) \\
\hline $63-68$ & 3 & $11 \%$ \\
\hline $69-74$ & 5 & $19 \%$ \\
\hline $75-79$ & 4 & $15 \%$ \\
\hline $80-84$ & 9 & $33 \%$ \\
\hline $85-89$ & 2 & $7 \%$ \\
\hline $90-94$ & 2 & $7 \%$ \\
\hline Amount & 25 & $100 \%$ \\
\hline
\end{tabular}

From the table, the distribution of the frequency of student learning outcomes taught by concept map learning strategies can be known that 8 people out of 25 students or $32 \%$ who still have learning outcomes under KKM (75), while 17 students or $68 \%$ of other students have grades above KKM.

The result of learning PPKn students who are taught with a concept map learning strategy the highest number of frequencies are in the class intervals $80-84$, while the least number of frequencies are in the interval class 85-90.

Based on hypothetical testing on the comparison of PPKn learning outcomes based on learning strategies obtained that the average learning outcomes of PPKn students who are taught with problem based learning strategies is 87.383 . While the results of learning PPKN students taught with a concept map learning strategy is 78.391. This indicates that the average learning outcome of PPKn students taught with problem based learning strategies is higher than the average learning outcomes of PPKn students who are taught with concept map learning. In other words, the learning outcomes of ppkn students who are taught with problem based learning strategies are higher than concept map learning strategies.

Learning Outcomes of PPKn Students Who Have High Learning Independence 
From the data obtained from the results of statistical calculations, it is known that the results of learning ppkn students who have high learning independence get the lowest score of 57, and the highest score is 100, with an average of 84.48; a variant of 92.08 and a standard deviation of 9.60. The distribution of the frequency of student learning outcomes that have high learning independence is presented in the following tabel below.

Table 3. Frequency Distribution of Learning Outcomes of Students who Have High Learning Independence

\begin{tabular}{|c|c|c|}
\hline Interval & Frequency & Percentage (\%) \\
\hline $67-72$ & 3 & $13 \%$ \\
\hline $73-78$ & 3 & $13 \%$ \\
\hline $79-84$ & 6 & $26 \%$ \\
\hline $85-90$ & 3 & $13 \%$ \\
\hline $91-96$ & 5 & $22 \%$ \\
\hline $97-102$ & 3 & $13 \%$ \\
\hline Amount & 23 & $100 \%$ \\
\hline
\end{tabular}

From the table, it can be known that 23 students from the entire sample (50 students) who have high learning independence. Based on statistical calculations it can also be known that 5 students (22\%) study results under KKM, while 18 students (78\%) other students have grades above KKM.

The result of learning PPKn students who have high learning independence with the highest number of frequencies are in the class intervals 79-84.

\section{Learning Outcomes of PpKn Students Who Have Low Learning Independence}

From data obtained and statistical calculation results are known that the results of learning PPKn students who have low learning independence get the lowest score of 63, and the highest score is 93, with an average of 80.42; variants of 51.98 and standard deviation of 7.21. The distribution of the frequency of scores of ppkn learning outcomes of students who have low learning independence is presented in the following tabel below.

Table 4. Frequency Distribution of Learning Outcomes of Students who Have Low Learning Independence

\begin{tabular}{|c|c|c|}
\hline Interval & Frequency & Percentage (\%) \\
\hline $63-68$ & 2 & $7 \%$ \\
\hline $69-74$ & 3 & $11 \%$ \\
\hline $75-80$ & 9 & $33 \%$ \\
\hline $81-86$ & 7 & $26 \%$ \\
\hline $87-92$ & 4 & $15 \%$ \\
\hline
\end{tabular}


The Influence of Learning Strategies and Self-Reliance on PPKn Learning Outcomes...

\begin{tabular}{|c|c|c|}
\hline $93-98$ & 2 & $7 \%$ \\
\hline Amount & 27 & $100 \%$ \\
\hline
\end{tabular}

From the table, it can be known that 27 students from the entire sample (50 students) who have low learning independence. Based on statistical calculations it can also be known that 5 students (19\%) study results under KKM, while 23 students (81\%) other students have grades above KKM.

PPKn learning outcomes of students who have low learning independence with the highest number of frequencies are in the class intervals of 75-80.

Based on hypothetical testing on the comparison of ppkn learning outcomes based on student learning independence obtained that the average learning outcomes of PPKn students who have high learning independence of 85.458. While the learning outcomes of PPKn students who have low learning independence is 80.317 . This shows that the average learning outcome of PPKn students who havehigh learning independence is higher than the average learning outcomes of ppkn students who have low learning independence. So the hypothesis testing rejects $\mathrm{H}_{\circ}$ and accepts $\mathrm{H}_{\mathrm{a}}$. With the conclusion that the results of learning PPKN students who have high learning independence is higher than students who havelow learning independence.

\section{Discussion}

Differences in Student Learning Outcomes Taught by Problem Based Learning Strategies Compared to Concept Map Learning Strategies

Starting from March 2020, Indonesia has been doingdistance learningbecause face-to-face learning is not possible during the Covid-19 pandemic. Since then, teachers have had difficulty in choosing the right learning model to use in the pandemic era. Therefore, this study seeks to find the right learning model used in PPKn subjects in the pandemic era.

The study compared two experimental groups, group A and group B. Based on the results of the study found that the results of learning in group $A$ is a group of students who are taught with a problem-based learning strategy obtained an average of 87,383 student learning outcomes. While the learning outcomes of students in group B are student learning outcomes taught using concept map learning strategies obtained an average of 78,391 learning outcomes. These results showed that there was a very significant difference between the learning outcomes of group A students compared to the student learning outcomes in group $\mathrm{B}$. 
When viewed more about the response of students in both groups when each of them is given treatment, namely by the application of problem based learning strategies and concept map learning strategies. Students in group A were more active in following the learning compared to group $B$, it said group A was more active because in group $A$ more students asked questions thus making the discussion activities more interesting. From the exposure, it can be concluded that the application of problem based learning strategy is considered very effective in improving students' learning outcomes in PPKn subjects, especially in "rights and obligations" material.

The application of problem based learning strategies requires students to learn independently, train problem solving skills, train critical thinking skills, train skills to work in groups, train interpersonal and communication skills, and train information search and processing skills. So that it has an open-minded insight, the knowledge gained will be more meaningful and not easily lost. This is in line with the opinion of Surya, et al who say that problem based learning is learning that involves students in solving a problem and provides opportunities for students to further express their creativity so as to improve student learning outcomes and creativity (Surya, Syahputra, \& Juniati, 2018).

The results of this study are similar to the results of research conducted by Tjahjana and Arief (2016) entitled "The Influence of Problem Based Learning Learning Model and Student Attitude towards The Learning Outcomes of Class X PPKn at SMK Negeri 1 Bojonggede Bogor Regency". In the study, it was found that the application of problem based learning model well can improve students' learning outcomes. Based on the description, it can be concluded that the use of problem based learning model can improve students' PPKn learning outcomes.

\section{Differences in Learning Outcomes of PPKn Students Who Have High Learning Independence Compared to Students Who Have Low Learning Independence}

The hypothesis of this study from the beginning suggests that students who have high learning independence get higher learning outcomes than students who have low learning independence. In other words, there is a significant influence between students' learning independence and the learning outcomes obtained. This statement can be proven from the results of research that shows that the average learning outcome of students who have high learning independence is 85,458 while the results of students who have low learning independence is 80.317 . 
The Influence of Learning Strategies and Self-Reliance on PPKn Learning Outcomes...

The results of this study are similar to Moore's statement that the independence of learning can affect students' learning outcomes, because with the independence in learning, students have a responsibility to the learning process and try their best to succeed in learning in order to obtain a satisfactory and proud learning outcome (Rusman, 2014, p. 365).

With self-reliance in learning, students have a sense of motivation to do the best in the task and in the learning process so that it will create good learning activities so that eventually it will achieve satisfactory learning outcomes. Self-reliance learning is a change in one's self that is the result of self-experience and practice without depending on others. In acting has the freedom to make decisions, judgments and responsible opinions without relying on others.

Children who have strong independence will not give up easily. Self-reliance can be demonstrated by the ability to solve problems faced with behavior. The personality of a child who has the characteristics of self-reliance positively affects his learning achievements. This can happen because the child starts with confidence in his own abilities consciously, regularly and disciplinedly trying earnestly to pursue learning achievements, they do not feel inferior and ready to overcome the problems that arise (Fatihah, 2016, p. 206).

\section{Conclusion}

Based on the discussion that has been described earlier, it can be drawn some conclusions such as the following:

1. There is a significant difference between the learning outcomes of ppkn students who are taught with problem based learning strategies compared to concept map learning strategies $\left(F_{\text {count }}=23,476\right.$ and sig. $\left.0.000<0.05\right)$.

2. The result of learning PPKN students who have higher learning independence compared to students who have low learning independence $\left(F_{\text {count }}=7,673\right.$ and sig. $0.008<0.05)$.

3. Thereis an interaction between learning strategies and learning independence in influencing students' ppkn learning outcomes ( $F_{\text {count }}=13,003$ and sig scores. 0.001 $<0.05)$. 


\section{Bibliography}

Fatihah, M. A. (2016). Hubungan antara Kemandirian Belajar dengan Prestasi Belajar PAI Siswa Kelas VI SDN Panularan Surakarta. Jurnal Attanbami, 1(2), 197-208. doi:10.22515/attarbawi.v1i2.200

Hasibuan, F. I. (2018). Pengaruh Model Pembelajaran Problem Based Learning (PBL) dan Motivasi Belajar Terhadap Hasil Belajar PKn Siswa di Kelas V SDIT Nurul 'Ilmi Medan. Medan: Universitas Negeri Medan.

Jailani, M. (2016). Pengaruh Strategi Peta Konsep dan Motivasi Belajar terhadap Hasil Belajar Pendidikan Agama Islam Siswa Kelas V SD Negeri 105288 Sei Rotan Kec.Percut Sei Tuan Kab. Deli Serdang. ESJ. Elementary School Journal PGSD FIP UNIMED, 5(1), 116-128. doi:10.24114/esjpgsd.v5i1.4150

Prasetyo, D. A., Perangin-angin, R. B., \& Saragi, D. (2020). The Influence of Learning Strategies and Social Interactions on the Learning Outcomes PKn of Grade V Students at SD Negeri 014711 Sipare-Pare in Batubara District. Jurnal IImiah Teunuleh, 1(2), 193-201. doi:10.51612/teunuleh.v1i2.32

Riswari, L. A., Yanto, H., \& Sunarso, A. (2018). The Effect of Problem Based Learning by using Demonstration Method on The Ability of Problem Solving. Journal of Primary Education, 7(3), 356-362. doi:10.15294/jpe.v7i3.24519

Rusman. (2014). Model-model Pembelajaran (Mengembangkan Profesionalisme Guru). Jakarta: Raja Grafindo Persada.

Sihotang, L., Setiawan, D., \& Saragi, D. (n.d.). The Effect of Learning Strategy and Self Confidence Toward Student's Learning Outcomes in Elementary School. IOSR Journal of Research \& Method in Education (IOSR-JRME), 7.

Surya, E., Syahputra, E., \& Juniati, N. (2018). Effect of Problem Based Learning Toward Mathematical Communication Ability and Self-Regulated Learning. Journal of Education and Practice, 9(6), 14-23.

Tjahjana, D., \& Arief, Z. A. (2016). Pengaruh Model Pembelajaran Problem Based Learning dan Sikap Peserta Didik Terhadap Hasil Belajar PPKn Kelas X di SMK Negeri 1 Bojonggede Kabupaten Bogor. Jurnal Teknologi Pendidikan, 5(1), 98-127. doi:10.32832/tek.pend.v5i1.490 